\title{
First access to the ocean beneath Ekströmisen, Antarctica, by means of hot-water drilling
}

\author{
U. Nixdorf, H. Oerter AND H. Miller \\ Alfred-Wegener-Institut für Polar- und Meeresforschung, D-27515 Bremerhaven, German]'
}

\begin{abstract}
ABSTR ACT. A hot-water drill developed during the past 2 years at AlfredWegener-Institut was used to penetrate Ekströmisen several times near the German wintering-over base, Neumayer $\left(70^{\circ} 39^{\prime} \mathrm{S}, 08^{\circ} 15^{\prime} \mathrm{W}\right)$. The drilling operation was very successful and the initial large diameter $(\geq 35 \mathrm{~cm})$ allowed easy access to the occan. One holc was uscd to install an ultrasonic echo-sounder which recorded the ablation at the ice-shelf bottom continuously. Another hole was destined for emplacement of a thermistor string throughout the $237 \mathrm{~m}$ thick ice shelf for ice-temperature measurements. Several CTD profiles in the $175 \mathrm{~m}$ deep water column and the analysis of water samples provided valuable data for the understanding of ice-shelfocean interactions.
\end{abstract}

\section{INTRODUCTION}

In many aspects, ice shelves play a very important role in the Antarctic environment. 'They are the main drainage areas for the West Antarctic ice sheet, thus controlling the mass balance of the ice sheet and participating in its dynamics (Doake and Vaughan, 1991). On the other hand, it is the ice-shell ocean interaction which plays an important role in forming the bottom water of the world's ocean ( Fahrbach and others, 1991). Ice-shelf movement, as well as oceancirculation systems and climatc change, have been described by numerical models (e.g. Detcrmann, 1991; Hellmer and Olbers, 1991; Jenkins and Doake, 1991; Huybrechts, 1992; Jacobs and others, 1992), which, however, depend on field measurements for calibration and validation purposes. Physical properties of the ice shelves (e.g. Oerter and others, 1992; Eicken and others, 1994) are needed as well as ablation and accumulation rates at the ice-shelf bottom (c.g. Grosfcld, 1993). The ocean currents are driven by the thermohaline conditions, and therefore measurements of salinity and seawater temperature are needed c.g. Nicholls and others, 1991 ) and especially current velocities which, however, were only once determined beneath an ice shelf (Osterhus and Orheim, 1992).

Compared with the two largest ice shelves in Antarctica, Ross and Filchner-Ronne Ice Shelves, Ekströmisen (Fig. 1) is small $\left(8700 \mathrm{~km}^{2}\right)$, and therefore it plays a minor role in the framework of global-change considerations. Nevertheless, the principal physics of icc shclves are independent of their areal extension and the wintering-over base Neumayer on Ekströmisen is quite easily accessible and therefore an optimum area for testing drilling equipment and various measuring devices, as well as starting pilot studies.

\section{THE HOT-WATER-DRILLING EQUIPMENT}

A proper means for penetrating ice bodies even 10 depths of several hundreds of meters is hot-water drills, as has becn proven by several field studies <e.g. Engelhardt and Determann, 1987; Nicholls and others, 1991; Iken and others, 1993). These hot-water drills enable a fast penetration rate but they need a tremendous logistic back-up. The hot-water drill developed at AWI consists

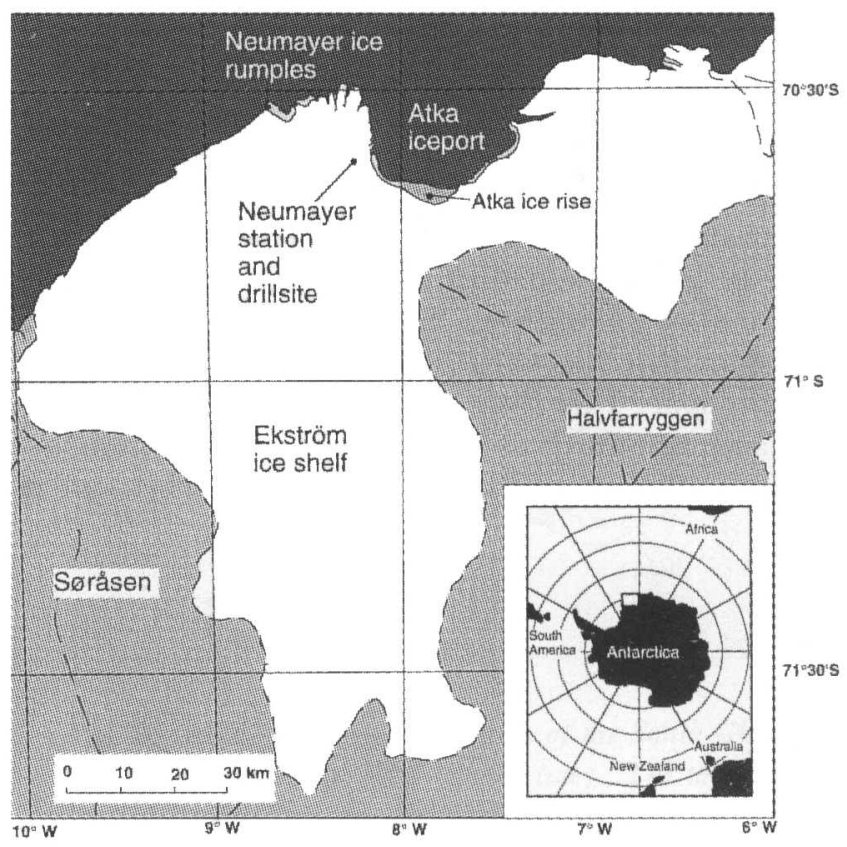

Fig. 1. Map of Ekströmisen (after Institut für Angewandte Geodäsie, 1989). The drill sile w'as located adjacent to the geophysical obseriatory of the German wintering-nzer base, Neumeyer. 
of six modified high-pressure cleaners, one winch-drum, the controlling electronics of the electrical winch, comprising display of hose tension as well as drilling speed and depth of the nozzle. The water needed is produced by melting snow in a water tank. Several pumps are used to supply the high-pressure heat exchangers and to recover used water from a separate hole in the firn, that reduces the energy needed for melting snow. Thus, more heat can be uscd for drilling. The capacity of the heat exchangers is $750 \mathrm{~kW}$, and the maximum capacity of the high-pressure pumps is approximately $901 \mathrm{~min}$ '. The drilling specd is controlled by the winch electronics, dependent on which are the total weight of the hose and drill head. Thus, it can be cnsurcd that the nozzle never touches the borehole bottom. Gravity always forces the nozzle to hang freely in the borehole, and a vertical borehole will be melted. This is necessary to enable undisturbed access to the borehole for water sampling and borehole logging.

\section{DRILLING DURING THE 1993 FIELD SEASON}

During the 1993 field season, the hot-water drill describcd above was used to penetrate the approximately $240 \mathrm{~m}$ lhick Ekströmisen three times. The drill sites were located adjacent to the geophysical observatory of the German over-wintering base, Neumayer. The geometry of the boreholes was determined with the aid of a caliper and inclination sonde. Immediately after drilling, the diameter was at least $35 \mathrm{~cm}$ and the inclination of the borehole deviated not more than a few degrees from the vertical. The time used for drilling itself was $12 \mathrm{~d}$; a total of $46 \mathrm{~d}$ was needed to get started and finished with installing all measurcment devices. The fuel consumption totalled 14 tonnes of diesel and 4 tonnes of gasoline.

One of the three boreholes was used to install an ultrasonic echo-sounder approximately $11.5 \mathrm{~m}$ below the ice-shelf bottom. The orientation of the sounder is upwards. For given time intervals, it determincs its distance to the bottom of the ice shelf. Thus, subglacial ablation or accumulation can be recorded directly. The data are recorded at the geophysical observatory. $\Lambda$ second hole was used to install a temperature string, with 11 thermistors, through the ice shelf. The data are transmitted via $\triangle$ RGOS to Bremerhaven. Through the third hole, a pressure gauge was lowered to the sea bottom for rccording tides, and a onc-conducter cable with two temperature sensors was lowered to the ocean bottom. Before these installations were completcd, the holes gave access to the ocean for six consecutive CTD profilings and water samplings. Two different water samplers were used on the samc cable, providing $150 \mathrm{mll}$ and 1.51 samples, respectively. A schematic drawing of the complete arrangement is shown in Figure 2.

\section{FIRST RESULTS}

Figure 3 a shows the variation of the distance between the echo-sounder and the icc-shelf bottom over a period of $154 \mathrm{~d}$ from 1 March to 1 August 1993. The distance varies considerably between 8 and $11.7 \mathrm{~m}$. These oscillations

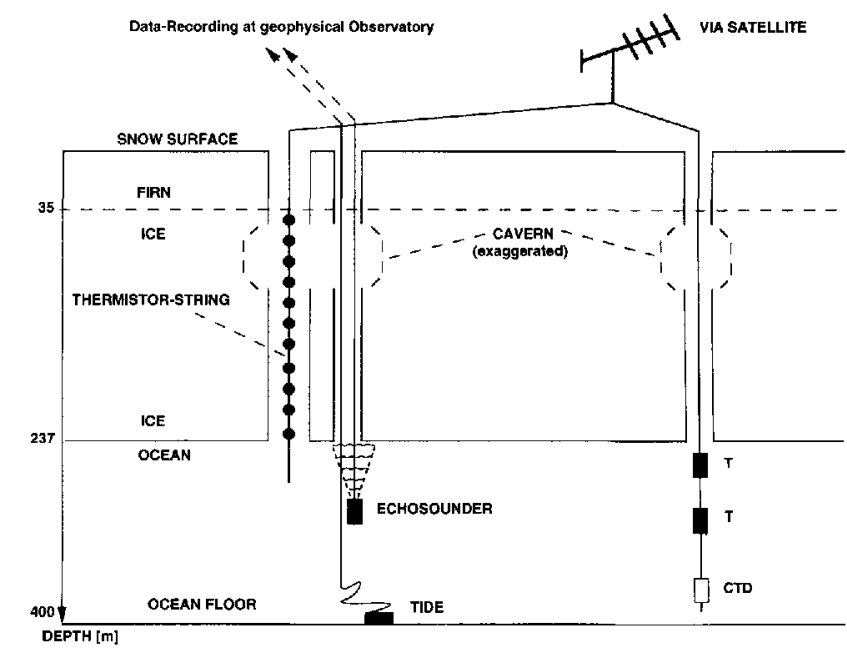

Fig. 2. Block diagram of the measuring devices in hotw'ater-drilled boreholes and underneath the ice shelf.

may be caused by obviously strong tidal currents entering bencath the ice shelf and moving the sounder along the vertical. By this movement, the distance to the ice-shelf bottom varies periodically, and will be dependent on the square of the speed of the sea-water current. An analysis of the frequency distribution of the distance variations (Fig. 3a) results in the spectrum of amplitudes given in Figure 3b. Evident are daily periods of 24, 12 and $6 \mathrm{~h}$, and with lower amplitude a period of $8 \mathrm{~h}$; a fortnightly period can also be secn. This means that the distance between echo-sounder and ice-shelf bottom varies with tidal frequencies; there is very little encrgy on other frequencies. This proves directly the existence of tidal currents underneath the ice shelf and that the echo-sounder follows the tide current. As the motion of the echo-sounder beneath the ice shelf is complex, we deduce the melting rates from the variation of the maximum distances as a first-order approximation. Though one cannot rule out the possibility that long-period changes in the tidal current may induce a change in slope of the base linc. we interpret this change in slope as varying melt rates under Fkströmisen. Seasonally varying melt rates have also been reported at other locations near ice fronts (Grosfeld and others, 1992). These "linear fits" are shown as lines 1 and 2 in Figure 3a. The different slopes result in ablation rates of $23 \mathrm{~cm}$ month ${ }^{1}$ during March and April and of $5 \mathrm{~cm}$ month ${ }^{1}$ from May to August. Thus, the melting rate close to the ice front (Fig. 1) shows a distinct variation with higher ablation in summer and lower ablation in winter. The deduced valucs of ablation agree quite well with model results calculated for the marginal area of Fkströmisen due to energy-balance considerations (Kipfstuhl, 1991). Thus, this ultrasonic ccho-sounder provides a method for direct ablation measurements and makes another valuable contribution to the mass-balance calculations of ice shelves. Furthermore, it should be possible to use the displacement of the echo-sounder to calculate the speed of thesc currents, if it has once been calibrated under defined conditions.

The influence of the tidal currents is also recognizable from the temperature data of the CTD profiles (Fig. 4a). Qualitatively, the sequence of the six profiles behaves similarly. The coldest water body with - in one case - a 


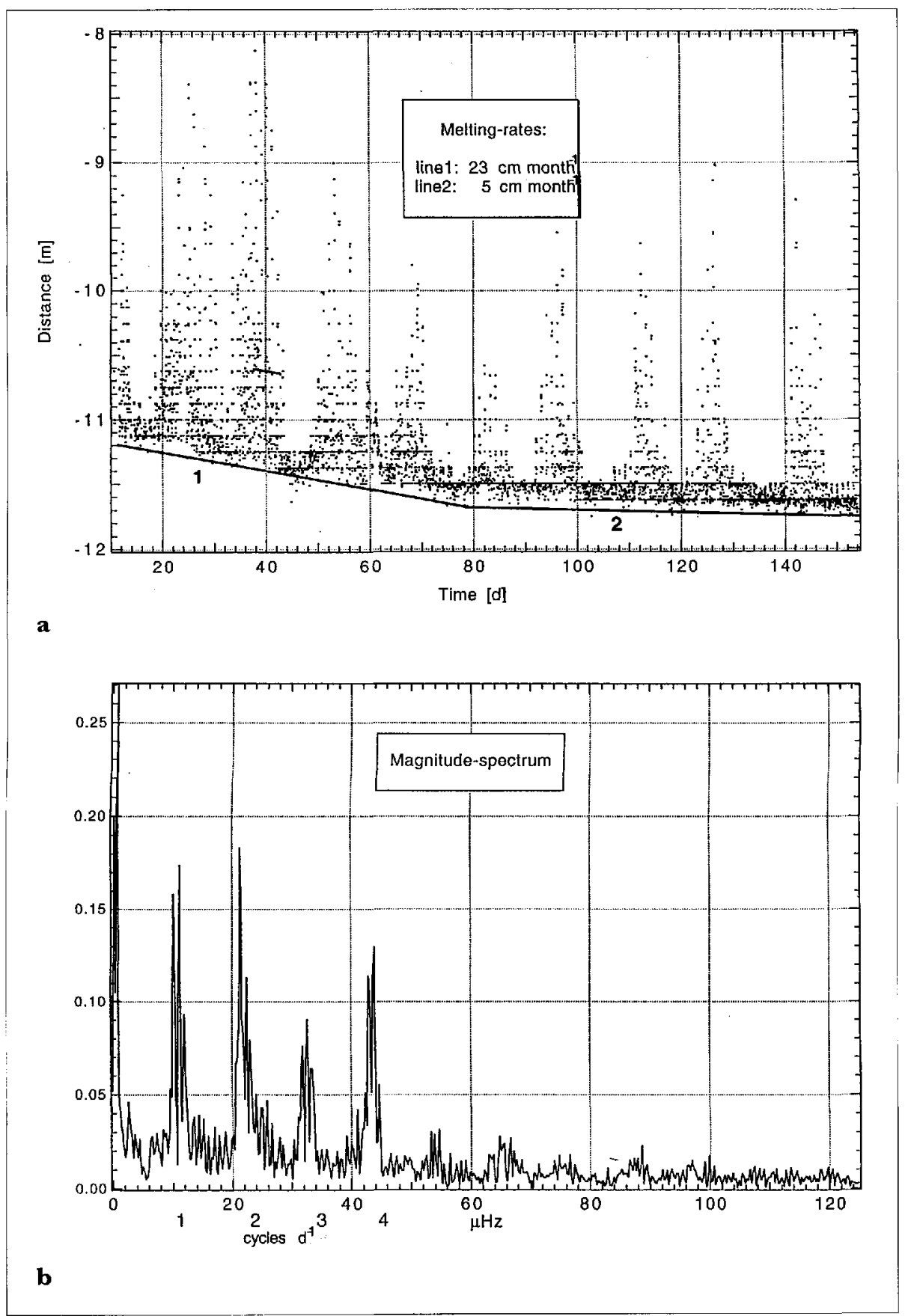

Fig. 3. a. Recorded distances between an echo-sounder underneath Ekströmisen and the ice-shelf bottom. The variations of the distance are due to displacement of the sounder by tidal currents. The deduced ablation rale varies between $23 \mathrm{~cm}^{\mathrm{month}}{ }^{-1}$ in "summer" and $5 \mathrm{~cm} \mathrm{month}{ }^{-1}$ in "winter". b. Spectrum amplitudes of the variations of recorded distances between an echosounder and the ice-shelf bottom (see Fig. $3 a$ ).

temperature below $-2.0^{\circ} \mathrm{C}$ appears closest to the ice shelf, immediately after the drilling had been completed. Afterwards, the temperature incrcases and decreases from minimum tempcratures below $1.90^{\circ} \mathrm{C}$ to maximum temperatures above $-1.85^{\circ} \mathrm{C}$ within a depth range between 200 and 260 dbar. Bclow 260 dbar, down to the sea bottom, a slightly increasing temperature is observed. The vertical width of the warm-water body, as well as the depth of the maximum temperature, varies with time. An explanation might be that, with the tidal current, relatively warm water flows under the ice shelf from the sea-icc-covered areas in front of and within Atka iceport. The salinity of the sea water under the ice shelf shows little variation (Fig. 4b) but increases with depth. The water samples taken through the boreholes are still under analysis for $\delta^{18} \mathrm{O}$ content and various nutrients. The results will enable a further description of the water masses and conclusions about their origin.

The tcmpcrature profiles of the ice shelf, as measured with the aid of the temperature string at several times, arc displayed in Figure 5. The horizontal lines indicate the depths of the thermistors (except $15 \mathrm{~m}$ ), each curve representing one set of measurements. One day after the drilling was finished, the temperature in the borehole was close to and even below the melting point. Almost 3 months are needed until the rcmaining heat of the hot-water drilling is drawn off and an undisturbed temperature profile (Grosfeld, 1993) is observed. This enables a qualitative study of the heat conductance in the ice shelf, as well as an estimate of the ice volume 

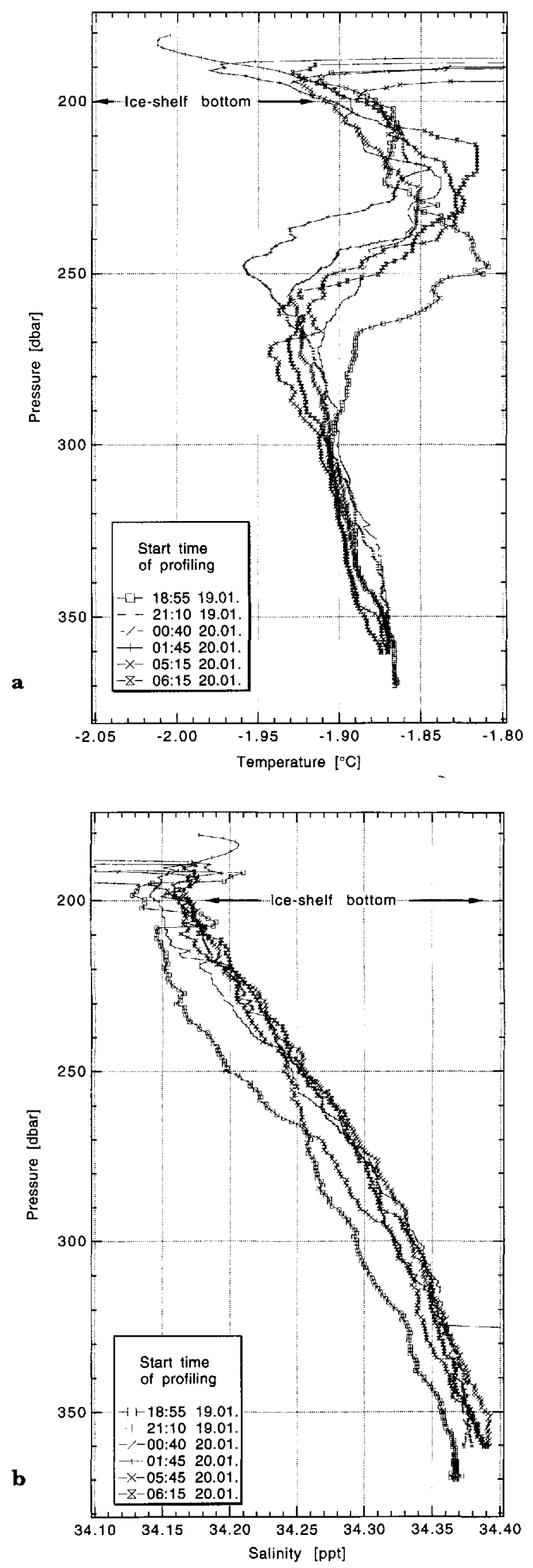

Fig. 4. a. Temperature profiles underneath Ekströmisen from 19 January, $1850 \mathrm{~h}$ to 20 January, 0610 h. b. Salinity profiles underneath Ekströmisen from 19 Jamuary, $1850 \mathrm{~h}$ to 20 January, $0610 \mathrm{~h}$. Salinity variations within the borehole are due to vertical water flow induced by the continuously operating submersible pump in the cavern (Fig. 2) and reaming of the borehole with fresh water between the CTD runs.

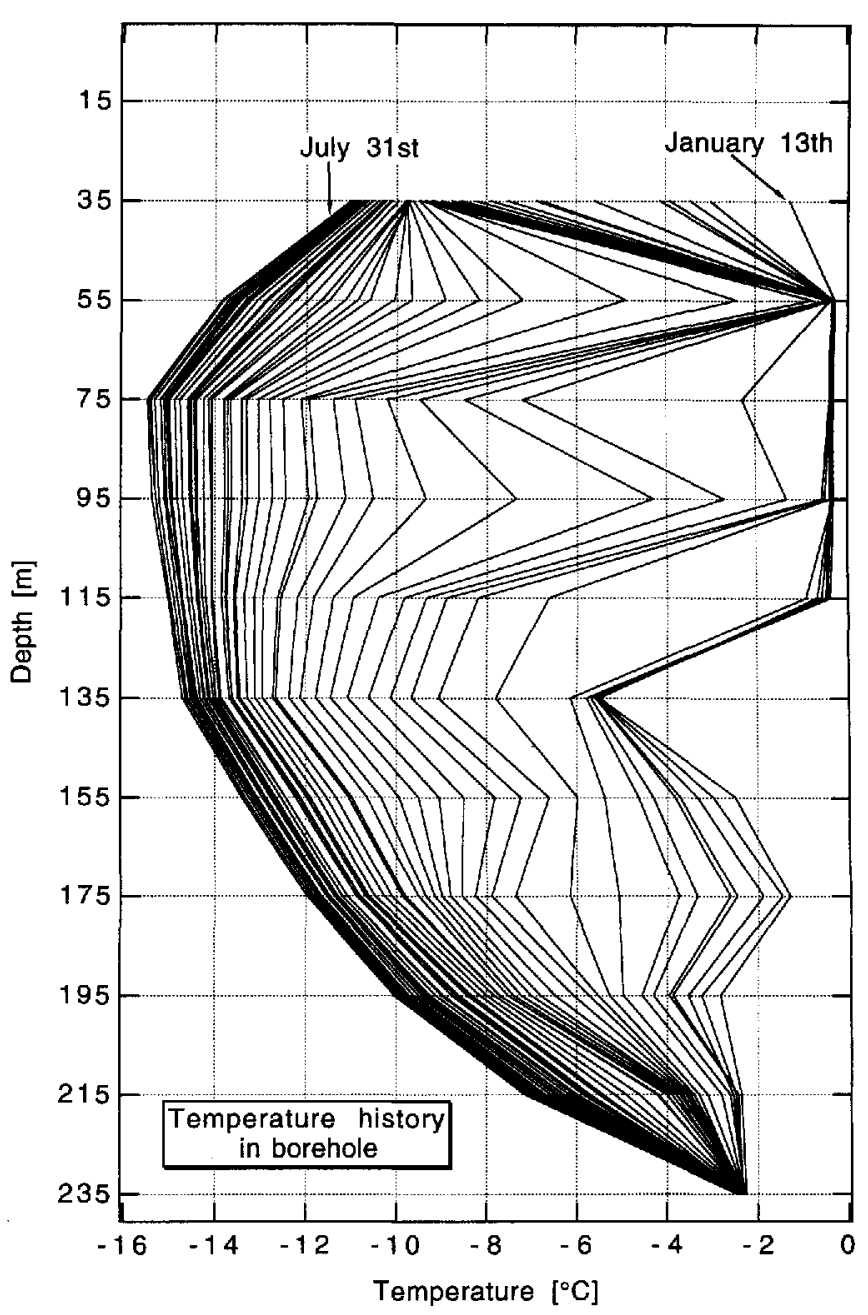

Fig. 5. Temperature distribution throughout Ekströmisen. The thermistor string is inserted in a hot-water drilled hole, drilled in Fanuary 1993.

influenced by the hot-water drilling. The lowermost thermistor is still surrounded by ice. It will be melted out within the next year and so a second possibility for ablation measurement is available.

\section{ACKNOWLEDGEMENTS}

Such a drilling operation can only be successful with good team work. Therefore, the authors would like to express gratitude to all who helped in preparing and carrying out the field work.

\section{REFERENGES}

Determann, J. 1991. Numerical modelling of ice shelf dynamics. Antarct. Sci., 3(2), 187-195.

Doake, C. S. M. and D. G. Vaughan. 1991. Rapid disintegration of the Wordie Ice Shelf in response to atmospheric warming. Nature, 350(6316), 328-330.

Eicken, H., H. Oerter, H. Miller, W. Graf and J. Kipfstuhl. 1994. Textural characteristics and impurity content of meteoric and marine ice in the Ronne Ice Shelf, Antarctica. 7. Glaciol., 40(135), $386-398$.

Engelhardt, H. and J. Determann. 1987. Borehole evidence for a thick layer of basal ice in the central Ronnc Ice Shelf. Nature, 327(6120), 318-319.

Fahrbach, E., M. Knoche and G. Rohardt. 1991. An estimate of water 
mass transformation in the southern Weddell Sea. Marine Chem.. 35 , $25-44$.

Grosfeld, K. 1993. Investigations on temperature regime and mass balance of the Filchner-Ronne Ice Shelf, Antarctica, with special intercst regarding molting and freczing processes. Ber. Polowforsh., 130.

Grosfeld, K.. N. Blindow and F. Thyssen. 1992. Bollom melting on FRIS: results from different methods. In Oerter, H., ed. FilcherRonne-Ice-Shelf-Programme, Report No. 6. Bremerhaven, Alfred-Wcgener-Institut, 2225

Hellmer, H. II. and D.J. Olbers. 1991. On the thermohaline circulation beneath the Filchner-Ronne ice shelves. Antart. Sci., 3 4), 433-442.

Huybrechts, P. 1992. The Antarctic ice sheet and environmental change: a three-dimensional modelling study. Ber. Polarforsch., 99.

Iken, A., K. Echelmever. W. Harrison and M. Funk. 1993. Mechanisms of fast llow in Jakobshavns Isbre, West Grecnland: Part 1. Measurcments of temperature and water level in deep boreholes. 7 . Glaciol. 39131), 15-25.

- Institut für Angcwandtc Gcodäsie, ed. 1989. Maps of ite shelf kinematics 1:500000, Ekströmisen SR29-30/SW, Antaktis. Frankfurt am Main, Institut für Angewandte Geodäsie.
Jacobs, S. S., H.H. Hellmer, C.S. M. Doake, A. Jenkins and R. M. Frolich. 1992. Melting of ice shelves and the mass balance of Antarctica. 7. Glaciol, 38 $130 ;, 375387$.

Jenkins, A. and C. S. M. Doake. 199L. Ice ocean interaction on Ronne lec Shelf, Antartica. 7. Geoplys. Res., 96(C) , 791-813.

KipfstuhI, J. 1991. On the formation of underwater ice and the growth and energy budget of the sea ice in Atka Bay, Antarctica. Ber. Polarforsch. 85.

Vicholls, K. W., K. Makinson and A.V. Robinson. 1991. Orean circulation beneath the Ronne Ice Shelf. Vature, 354 6350 , 221-223.

Oerter, H. and 6 others. 1992. Evidence for basal marine ice in the Filchner-Ronne Ice Shclf. Tature, 358 6385), 399-401.

Osterhus, S. and O. Orheim. 1992. Studies through Jutulgryta. Fimbulisen in the $1991 / 92$ season. In Oerter. H., ed. Filcher-RommeIce-Shelf-Programme, Report No. 6. Bremerhaven, Alfred-llegenerInstitut, 103-109.

The accuracy of references in the text and in this list is the responsibility of the authors, to whom queries should be addressed. 